\title{
METAL CONTAMINATIONS IN FIVE FISH SPECIES FROM BLACK, MARMARA, AEGEAN AND MEDITERRANEAN SEAS, TURKEY
}

\author{
MUSTAFA TÜRKMEN ${ }^{\prime *}$ AYSUN TÜRKMEN² YALÇIN TEPE ${ }^{1}$ \\ ${ }^{1}$ Faculty of Fisheries and Aquaculture, Mustafa Kemal University, 31040, Antakya, Hatay, Turkey \\ ${ }^{2}$ Food quality control laboratory of hatay, ministry of agriculture and rural affairs, 31000 antakya, hatay, turkey \\ (Received: 31 July 2007 - Accepted: 11 January 2008)
}

\begin{abstract}
The concentrations of cadmium, copper, chromium, copper, iron, manganese, nickel, zinc and lead in muscle and liver tissues of the fish samples collected from seven stations in the coastal waters of Turkey and were determined. Iron showed the highest levels in both tissues of fish and all stations. Following Fe; $\mathrm{Zn}$ generally showed the second highest levels. Metal concentrations in edible parts of fish species were $0.02-0.30 \mathrm{mg} \mathrm{kg}^{-1}$ for cadmium, $0.04-0.26 \mathrm{mg} \mathrm{kg}^{-1}$ for cobalt, $0.07-1.19 \mathrm{mg} \mathrm{kg}^{-1}$ for chromium, $0.34-16.7 \mathrm{mg} \mathrm{kg}^{-1}$ for copper, $18.5-72.3 \mathrm{mg} \mathrm{kg}^{-1}$ for iron, $0.07-2.58 \mathrm{mg} \mathrm{kg}^{-1}$ for manganese, $0.01-2.78 \mathrm{mg} \mathrm{kg}^{-1}$ for nickel, $0.04-1.34$ $\mathrm{mg} \mathrm{kg}^{-1}$ for lead, 3.36-42.6 mg kg-1 for zinc respectively. In general, metal concentrations in livers were higher than those in muscles. Cadmium, chromium and lead concentrations in muscles of fish from some stations were higher than permissible safety levels for human uses.
\end{abstract}

Keywords: Metals, Fish tissues, PTWI, Turkish seas

\section{INTRODUCTION}

Turkey is surrounded by four different seas (Black, Marmara, Aegean and Mediterranen seas) with $8333 \mathrm{~km}$ long coastal line and fishing is one of the biggest income sources for the country. The four seas around Turkey each reflect a different ecological character, salinity is 18 per thousand in the Black Sea, 23 per thousand in the Marmara Sea, 32 per thousand in the Aegean Sea and 38 per thousand in the Mediterranean Sea.

Heavy metals can be accumulated by marine organisms through a variety of pathways, including respiration, adsorption and ingestion ${ }^{1}$. Over the last few decades the marine environment has been contaminated by persistent pollutants of agriculture and industrial origin. Heavy metal contamination has been identified as a concern in coastal environment, due to discharges from industrial wastes, agricultural and urban sewage. The levels of heavy metal are known to increase drastically in marine environment through mainly anthropogenic activities. This result either with the complete extinction of some non tolerant species from these environments or they cause structural and functional damage to the organisms by interfering with their physiological and biochemical mechanisms. Fish are good indicators for the long term monitoring of metal accumulation in the marine environment. Therefore, numerous studies have been carried out on metal accumulation in different fish species ${ }^{2-6}$. Many species of marine benthic fish have been shown to reflect ambient metal concentrations ${ }^{7-8}$.

The aim of this study was to determine the levels of cadmium, cobalt, chromium, copper, iron, manganese, lead, nickel and zinc in muscle and liver of five fish species from Black, Marmara, Aegean and Mediterranean seas.

\section{EXPERIMENTAL}

Sampling: Fish samples were collected in $5-40 \mathrm{~m}$ depths by using various fishing methods such as bottom trawl, fishing nets, longline fishing, fly fishing and handline fishing with commercial fishing vessels from six different sites in the coastal waters of Turkey from February to July 2005. These sampling sites are Sinop (SNP) and Bartın (BRT) in the Black Sea; Yalova (YLV) in Marmara Sea, northern Aegean Sea (NAS) and central Aegean Sea (CAS) in Aegean Sea, Antalya Bay (AB) and İskenderun Bay (IB) in Mediterranean Sea (Figure I). Five fish species (69 samples) examined in this study were summarized in Table I. These species are mediterranean horse mackerel (Trachurus mediterraneus), annular seabream (Diplodus annularis), brown ray (Raja miraletus), common stingray (Dastiyatis pastinaga) and greater amberjack (Seriola dumerili). Total length and weight of the samples brought to laboratory on ice after collection were measured to the nearest millimeter and gram before dissection. Approximately $1 \mathrm{~g}$ sample of muscle and entire liver from each fish were dissected, washed with distilled water, weighed, packed in polyethylene bags and stored at $-18{ }^{\circ} \mathrm{C}$ until chemical analysis.

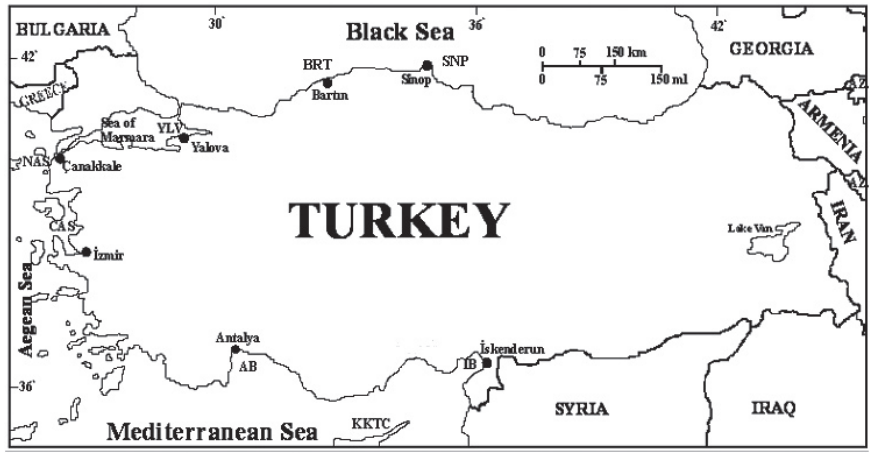

Figure I. The sampling locations from Turkey waters (Sampling locations are SNP: Sinop; BRT: Bartın, YLV: Yalova, NAS: North Aegean Sea, CAS: Central Aegean Sea, AB: Antalya Bay, IB: İskenderun Bay).

Table I. Biometric data (Mean \pm SE) of fish from Turkey seas

\begin{tabular}{|c|c|c|c|c|}
\hline Locations & Species & $\mathrm{N}$ & $\begin{array}{l}\text { Length } \\
(\mathrm{cm})\end{array}$ & Weight $(\mathrm{g})$ \\
\hline Sinop (SNP) & $\begin{array}{l}\text { Trachurus } \\
\text { mediterraneus }\end{array}$ & 5 & $17.4 \pm 0.5$ & $28.8 \pm 1.6$ \\
\hline Bartın (BRT) & $\begin{array}{l}\text { Trachurus } \\
\text { mediterraneus }\end{array}$ & 4 & $14.5 \pm 0.2$ & $26.6 \pm 2.1$ \\
\hline Yalova (YLV) & Diplodus annularis & 5 & $16.0 \pm 0.5$ & $85.3 \pm 7.7$ \\
\hline $\begin{array}{l}\text { North Aegean Sea } \\
\text { (NAS) }\end{array}$ & $\begin{array}{l}\text { Trachurus } \\
\text { mediterraneus } \\
\text { Diplodus annularis }\end{array}$ & 5 & $\begin{array}{l}15.1 \pm 0.2 \\
17.8 \pm 0.3\end{array}$ & $\begin{array}{l}29.0 \pm 1.1 \\
101 \pm 4.9\end{array}$ \\
\hline $\begin{array}{l}\text { Central Aegean } \\
\text { Sea (CAS) }\end{array}$ & Diplodus annularis & 7 & $19.3 \pm 0.2$ & $99.4 \pm 3.1$ \\
\hline Antalya Bay (AB) & $\begin{array}{l}\text { Diplodus annularis } \\
\text { Raja miraletus } \\
\text { Dastiyatis pastinaga }\end{array}$ & $\begin{array}{l}7 \\
5 \\
3\end{array}$ & $\begin{array}{l}14.3 \pm 0.8 \\
47.3 \pm 3.1 \\
37.2 \pm 0.6\end{array}$ & $\begin{array}{l}50.5 \pm 2.9 \\
664 \pm 98 \\
260 \pm 5.1 \\
\end{array}$ \\
\hline $\begin{array}{l}\text { İskenderun Bay } \\
\text { (IB) }\end{array}$ & $\begin{array}{l}\text { Trachurus } \\
\text { mediterraneus } \\
\text { Diplodus annularis } \\
\text { Seriola dumerili }\end{array}$ & $\begin{array}{l}7 \\
5\end{array}$ & $\begin{array}{l}19.2 \pm 0.4 \\
16.3 \pm 0.2 \\
19.9 \pm 0.7\end{array}$ & $\begin{array}{l}60.2 \pm 3.7 \\
66.4 \pm 2.6 \\
97.4 \pm 9.8\end{array}$ \\
\hline
\end{tabular}


Chemical Analyses: Special care was taken to prevent metal contamination of the samples by the laboratory equipments, and tissues were dissected by plastic knife and all laboratory-ware was soaked in $2 \mathrm{M} \mathrm{HNO}_{3}$ for $48 \mathrm{~h}$, and rinsed five times with distilled water, and then five times with deionized water prior to use. All tissue samples were transferred into $100 \mathrm{ml}$ Teflon beakers. There after, $10 \mathrm{ml}$ ultrapure concentrated nitric acid was added slowly to the sample. The Teflon beaker was covered with a watch glass, and heated at 200 ${ }^{\circ} \mathrm{C}$ on a hot plate for $3 \mathrm{~h}$, until the solution evaporate slowly to near dryness. Two milliliters of $1 \mathrm{~N} \mathrm{HNO}_{3}$ was added to the residue and the solution was evaporated again on the hot plate. By repeating the additional digestion twice, all organic materials in each sample were completely digested. After cooling, $2.5 \mathrm{ml}$ of $1 \mathrm{~N} \mathrm{HNO}_{3}$ was added to digested residue and was transferred to $25 \mathrm{ml}$ volumetric flasks, then diluted to level with deionized water. Before analysis, the samples were filtered through a $0.45 \mu \mathrm{m}$ nitrocellulose membrane filter. Sample blanks were prepared in the laboratory in a similar manner to the field samples. ${ }^{9}$. Metal contents were expressed as $\mathrm{mg} / \mathrm{kg}$ wet weight.

All samples were analyzed three times for $\mathrm{Cd}, \mathrm{Co}, \mathrm{Cr}, \mathrm{Cu}, \mathrm{Fe}, \mathrm{Mn}, \mathrm{Ni}, \mathrm{Pb}$ and $\mathrm{Zn}$ by Inductively Coupled Plasma-Atomic Emission Spectrometry (ICPAES) (Varian Model-Liberty Series II). Standard solutions were prepared from stock solutions (Merck, multi element standard). A Dorm-2 certified dogfish tissue was used as the calibration verification standard. Recoveries between $90 \%$ and $110 \%$ were accepted to validate the calibration. All specimens were run in batches that included blanks, a standard calibration curve, two spiked specimens, and one duplicate. The results showed good agreement between the certified and the analytical values, the recovery of elements being partially complete for most of them (Table II).
Table II. Concentrations of metals found in Certified Reference Material Dorm-2 (dogfish muscle) from the NRC, Canada (means \pm standard errors, in $\mathrm{mg} / \mathrm{kg}$ dry wt)

\begin{tabular}{|l|l|l|l|}
\hline Metals & Certified \pm SE & Observed \pm SE $^{\mathrm{a}}$ & Recovery $(\%)$ \\
\hline Cadmium & $0.043 \pm 0.008$ & $0.047 \pm 0.007$ & 109 \\
\hline Cobalt & $0.182 \pm 0.031$ & $0.169 \pm 0.031$ & 93 \\
\hline Chromium & $34.7 \pm 5.5$ & $33.9 \pm 6.4$ & 98 \\
\hline Copper & $2.34 \pm 0.16$ & $2.48 \pm 0.21$ & 106 \\
\hline Iron & $142 \pm 10$ & $139 \pm 8.7$ & 98 \\
\hline Manganese & $3.66 \pm 0.34$ & $3.57 \pm 0.37$ & 97 \\
\hline Nickel & $19.4 \pm 3.1$ & $20.1 \pm 2.9$ & 104 \\
\hline Lead & $0.065 \pm 0.007$ & $0.069 \pm 0.008$ & 106 \\
\hline Zinc & $26.6 \pm 2.3$ & $24.9 \pm 2.8$ & 94 \\
\hline
\end{tabular}

a Each value is the average of fifteen determinations Statistical Analyses:

A logarithmic transformation was done on the data to improve normality. To test the differences between the concentrations in tissues of the samples from different sites, one way ANOVA was performed. Post hoc test (Tukey) was applied to determine statistically significant differences following ANOVA. Possibilities less than 0.05 were considered statistically significant $(\mathrm{p}<0.05)$.

\section{RESULTS AND DISCUSSION}

Concentrations of nine metals in the muscle and liver of five fish species from Turkish coastal waters are shown in Table III and Figure II. Metal concentrations in livers of examined species were generally higher than those in muscles. Iron was the highest in both muscle and liver of analyzed species in this study, followed by $\mathrm{Zn}$. On the other hand, cadmium and cobalt were generally the lowest. Similar situations were reported many researchers ${ }^{3-5,10}$.

Table III. Mean metal contents with standard error in the tissues of the examined species from Black, Marmara, Aegean and Mediterranean seas, Turkey $(\mathrm{mg} / \mathrm{kg}$ wet wt)*

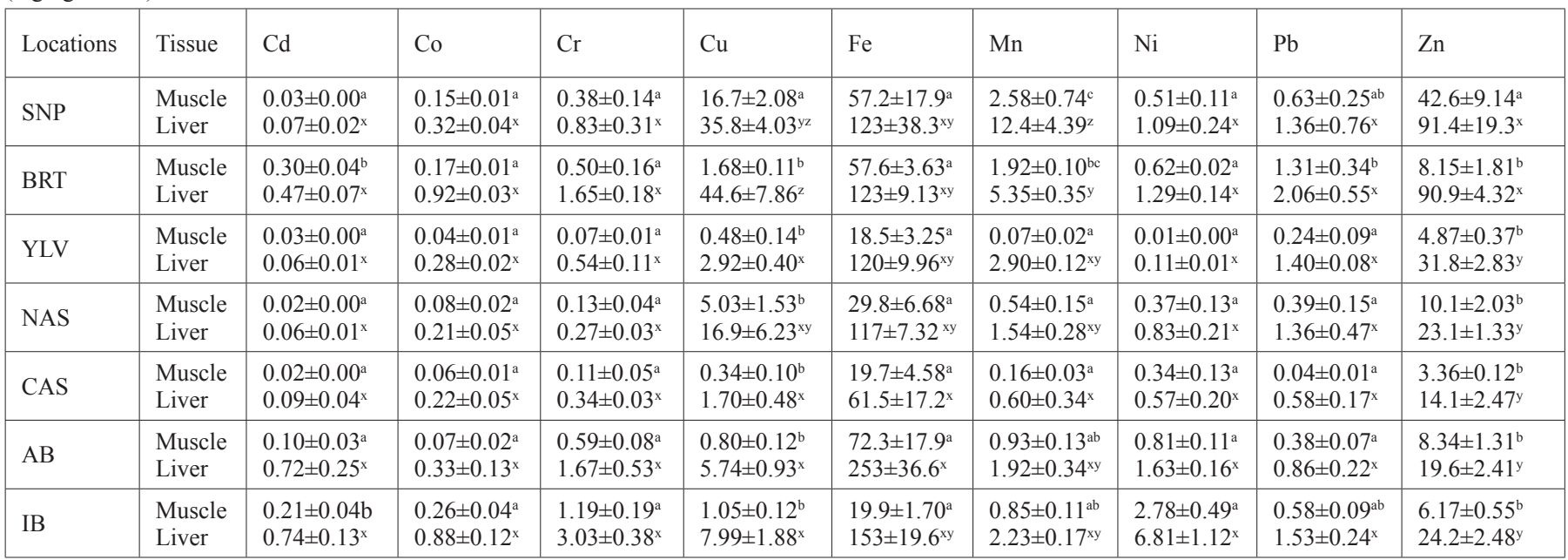

"Vertically, letters a, b and c show differences among sites for muscles; $\mathrm{x}, \mathrm{y}$ and $\mathrm{z}$ for livers. Within columns, means with the same letter are not statistically significant, $\mathrm{p}>0.05$

The lowest and highest cadmium concentrations in analyzed fish were 0.02 mg kg-1 in NAS and CAS, and $0.30 \mathrm{mg} \mathrm{kg}^{-1}$ in BRT for muscles, and 0.06 $\mathrm{mg} \mathrm{kg}^{-1}$ in YLV and NAS, and $0.74 \mathrm{mg} \mathrm{kg}^{-1}$ in IB for livers. Cadmium levels in the literature were reported as $<0.01-0.04 \mathrm{mg} \mathrm{kg}^{-1}$ for muscles of fish in southeastern Aegean Sea, Turkey ${ }^{11}, 0.03-0.12 \mathrm{mg} \mathrm{kg}^{-1}$ for muscles and 0.02$0.35 \mathrm{mg} \mathrm{kg}^{-1}$ for livers of fish in Tuzla Lagoon, Mediterranean region, Turkey ${ }^{4}$, $0.02-1.32 \mathrm{mg} \mathrm{kg}^{-1}$ for muscles of fish from internal markets of India ${ }^{12}, 0.1-1.2$ $\mathrm{mg} / \mathrm{kg}$ for muscles of fish from lakes in Tokat, Turkey ${ }^{13}$. Provisional tolerable weekly intake (PTWI) depends on the amount, consumption period and contamination level of consumed food. PTWI for cadmium was established
$0.007 \mathrm{mg} \mathrm{Cd}$ per $\mathrm{kg}$ body weight/week and $0.49 \mathrm{mg} \mathrm{Cd}$ per week for $70 \mathrm{~kg}$ person $^{14}$. For example, because $\mathrm{Cd}$ level is the highest $(30 \mathrm{mg} / \mathrm{kg})$ in muscles of fish species in BRT, an adult person who consumed $1.63 \mathrm{~kg} / \mathrm{week}(0.49 \mathrm{mg}$ $\mathrm{x} 1 \mathrm{~kg} / 0.30 \mathrm{mg}$ ) from fish in BRT would reach PTWI. The mean daily fish consumption in Turkey is $20 \mathrm{~g}$ per person ${ }^{15}$. This is equivalent to $140 \mathrm{~g}$ per person per week. Then, estimated PTWI ranges from $0.003 \mathrm{mg}$ ( $140 \mathrm{~g} \mathrm{x} 0.02$ $\mathrm{mg} / 1000 \mathrm{~g})$ to $0.042 \mathrm{mg}(140 \mathrm{~g} \mathrm{x} 0.30 \mathrm{mg} / 1000 \mathrm{~g})$ per person for cadmium in muscles of fish. As can be seen, the estimated PTWI of cadmium is below the established PTWI. 

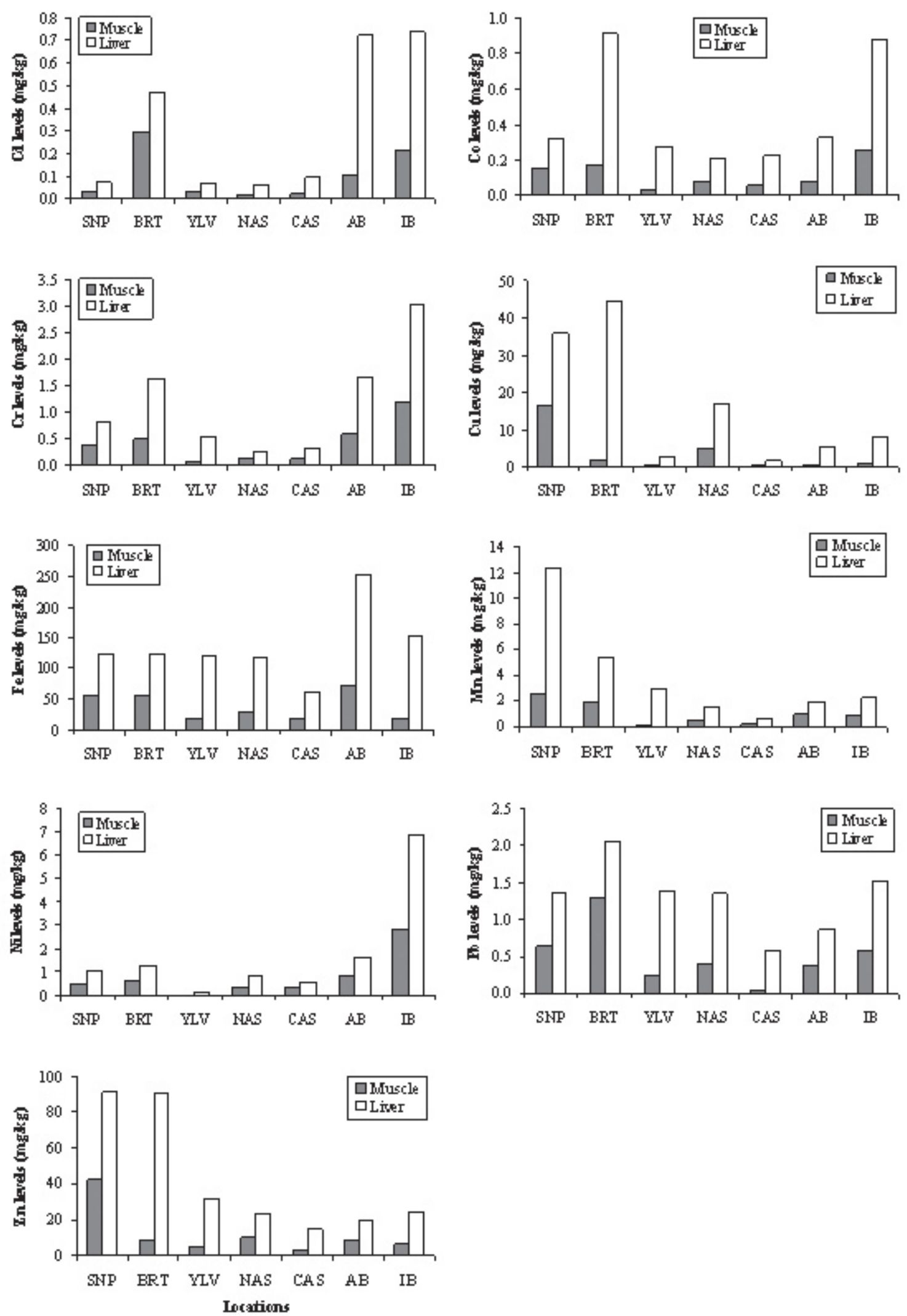

Figure II. Metal concentrations in fish from Black, Marmara, Aegean and Mediterranean seas, Turkey; Sinop (SNP), Bartın (BRT), Yalova (YLV), North Aegean Sea (NAS), Central Aegean Sea (CAS), Antalya Bay (AB), İskenderun Bay (IB). 
The minimum and maximum cobalt concentrations obtained were 0.04 $\mathrm{mg} / \mathrm{kg}$ in YLV and $0.26 \mathrm{mg} / \mathrm{kg}$ in IB for muscles, and $0.21 \mathrm{mg} / \mathrm{kg}$ in NAS and $0.92 \mathrm{mg} / \mathrm{kg}$ in BRT for livers. Cobalt concentrations in the literature have been reported in the range of $0.02-0.67 \mathrm{mg} / \mathrm{kg}$ for muscles of fish from the fish markets in India ${ }^{11}, 0.006-0.244 \mathrm{mg} / \mathrm{kg}$ for muscles of fish from the coasta waters of the Caspian Sea ${ }^{16}, 0.04-0.41 \mathrm{mg} / \mathrm{kg}$ for muscles and $0.14-0.51 \mathrm{mg} / \mathrm{kg}$ for livers of fish from Turkish seas ${ }^{17}$. Our results were generally in agreement with literature. There is no information about maximum permissible cobalt limits in fish tissues in Turkish standards ${ }^{18}$

The lowest and highest chromium concentrations in analyzed fish were $0.75 \mathrm{mg} / \mathrm{kg}$ in YLV and $1.19 \mathrm{mg} / \mathrm{kg}$ in IB for muscles, and $0.27 \mathrm{mg} / \mathrm{kg}$ in NAS and $3.03 \mathrm{mg} / \mathrm{kg}$ in IB for livers. In the literature, chromium concentrations in fish have been reported in the range of $0.08-1.4 \mathrm{mg} / \mathrm{kg}$ for muscles of fish from the coastal waters of the Caspian $\mathrm{Sea}^{16}, 0.95-1.98 \mathrm{mg} / \mathrm{kg}$ for muscles of fish from the Black and Aegean seas ${ }^{10}, 0.59-1.69 \mathrm{mg} / \mathrm{kg}$ for muscles of fish from the İskenderun bay ${ }^{19}, 0.10-1.60 \mathrm{mg} / \mathrm{kg}$ for muscles and $0.20-3.88$ for livers of fish from coastal waters of Turkey ${ }^{5}$. Although there is no information about maximum permissible chromium levels in fish tissues in Turkish standards ${ }^{18}$, the maximum permissible chromium level reported by $\mathrm{FAO}^{20}$ for fish are 1.0 $\mathrm{mg} / \mathrm{kg}$. Chromium levels in IB for the muscles and BRT, AB and IB for livers in this study were found to be higher than permissible limits reported by $\mathrm{FAO}^{20}$.

The minimum and maximum copper levels were $0.34 \mathrm{mg} / \mathrm{kg}$ in CAS and $16.7 \mathrm{mg} / \mathrm{kg}$ in SNP for muscles, and $1.70 \mathrm{mg} / \mathrm{kg}$ in CAS and $44.6 \mathrm{mg} / \mathrm{kg}$ in BRT for livers. Copper levels in the literature have been reported in the range of $1.57 \mathrm{mg} / \mathrm{kg}$ in muscles of fish from İskenderun bay ${ }^{3}, 0.7-27 \mathrm{mg} / \mathrm{kg}$ in muscles and $3.1-323 \mathrm{mg} / \mathrm{kg}$ in livers of fish from Lake Budi, IX Region, Chile $^{21},<3.17 \mathrm{mg} / \mathrm{kg}$ in muscles and $305 \mathrm{mg} / \mathrm{kg}$ in livers of fish from EsmorizParamos coastal lagoon ${ }^{22}, 0.57 \mathrm{mg} / \mathrm{kg}$ in muscles of Pagrus pagrus ${ }^{23}, 0.32$ $6.48 \mathrm{mg} / \mathrm{kg}$ for muscles and 5.29-14.9 for livers of fish from Turkish seas ${ }^{17}$ Our results were generally in agreement with literature. The Joint FAO/WHO Expert Committee on Food Additives established a PTWI for copper of $3.5 \mathrm{mg}$ / $\mathrm{kg}$ body weight/week ${ }^{24}$ which was equivalent to $245 \mathrm{mg} /$ week for a $70 \mathrm{~kg}$ adult. By using the means of weekly fish consumption in Turkey of $140 \mathrm{~g}$ per person ${ }^{14}$ and minimum and maximum copper levels in examined fish, weekly intake calculated ranged from $0.048 \mathrm{mg}(140 \mathrm{~g} \mathrm{x} 0.34 \mathrm{mg} / 1000 \mathrm{~g})$ to $2.34 \mathrm{mg}(140 \mathrm{~g}$ $\mathrm{x} 16.7 \mathrm{mg} / 1000 \mathrm{~g}$ ) per person for copper in muscles of fish. As can be seen, the estimated PTWI of zinc in this study is far below the established PTWI.

The lowest and highest iron levels in fish were $18.5 \mathrm{mg} / \mathrm{kg}$ in YLV and $72.3 \mathrm{mg} / \mathrm{kg}$ in $\mathrm{AB}$ for muscles, and $61.5 \mathrm{mg} / \mathrm{kg}$ in CAS and $253 \mathrm{mg} / \mathrm{kg}$ in $\mathrm{AB}$ for livers. Iron contents in the literature have been reported in the range of $8.87-18.8 \mathrm{mg} / \mathrm{kg}$ in muscles of fish from İskenderun bay ${ }^{19}, 7.16-16.5 \mathrm{mg} / \mathrm{kg}$ in muscles and 48.1-384 mg/kg in livers of fish from Tuzla Lagoon, Mediterranean sea region ${ }^{4}, 1.49-3.69 \mathrm{mg} / \mathrm{kg}$ in muscles and $19.5-21.6 \mathrm{mg} / \mathrm{kg}$ in livers of fish from Mediterranean sea region ${ }^{6}$. Our iron concentrations were generally in agreement with literature. The Joint FAO/WHO Expert Committee on Food Additives established a PTWI for iron of $5.6 \mathrm{mg} / \mathrm{kg}$ body weight $/$ week $^{24}$ which was equivalent to $392 \mathrm{mg} /$ week for a $70 \mathrm{~kg}$ adult. By using the means of weekly fish consumption in Turkey of $140 \mathrm{~g}$ per person ${ }^{15}$ and minimum and maximum iron levels in fish, weekly intake calculated ranged from $2.59 \mathrm{mg}$ (140 g x $18.5 \mathrm{mg} / 1000 \mathrm{~g})$ to $10.12 \mathrm{mg}(140 \mathrm{~g} \mathrm{x} 72.3 \mathrm{mg} / 1000 \mathrm{~g})$ per person for iron in muscles of fish. As can be seen, the estimated PTWI of lead in this study is below the established PTWI.

The minimum and maximum manganese contents were found as $0.07 \mathrm{mg}$ / $\mathrm{kg}$ in YLV and $2.58 \mathrm{mg} / \mathrm{kg}$ in SNP for muscles, and $0.60 \mathrm{mg} / \mathrm{kg}$ in CAS and $12.4 \mathrm{mg} / \mathrm{kg}$ in SNP for livers. Manganese in the literature have been reported in the range of $0.09-9.23 \mathrm{mg} / \mathrm{kg}$ in muscles of fish from coastal waters of Caspian $\mathrm{sea}^{16}, 0.16 \mathrm{mg} / \mathrm{kg}$ in muscles of Pagrus pagrus ${ }^{23}, 0.14-3.36 \mathrm{mg} / \mathrm{kg}$ in muscles of fish from Indian markets ${ }^{12}, 0.07-0.45 \mathrm{mg} / \mathrm{kg}$ in muscles and $0.89-3.32 \mathrm{mg} /$ $\mathrm{kg}$ in livers ${ }^{6}, 0.08-1.12 \mathrm{mg} / \mathrm{kg}$ for muscles and $0.72-7.33 \mathrm{mg} / \mathrm{kg}$ for livers of fish from coastal waters of Turkey ${ }^{5}$. There is no information about maximum permissible manganese concentrations in fish tissues in Turkish standards ${ }^{18}$.

The lowest and highest nickel levels in fish were found as $0.01 \mathrm{mg} / \mathrm{kg}$ in YLV and $2.78 \mathrm{mg} / \mathrm{kg}$ in IB for muscles, and $0.11 \mathrm{mg} / \mathrm{kg}$ in YLV and 6.81 $\mathrm{mg} / \mathrm{kg}$ in IB for livers. Nickel contents in the literature have been reported in the range of $0.06-0.39 \mathrm{mg} / \mathrm{kg}$ in muscles of fish Ria de Averio, Portugal ${ }^{25}$ $0.03-0.69 \mathrm{mg} / \mathrm{kg}$ in muscles of fish from Indian markets ${ }^{12}, 0.66-1.59 \mathrm{mg} / \mathrm{kg}$ in muscles of fish from İskenderun bay, Mediterranean sea ${ }^{19}, 0.009-0.011 \mathrm{mg} / \mathrm{kg}$ in muscles and $0.07-0.10 \mathrm{mg} / \mathrm{kg}$ in livers of fish from Mediterranean region ${ }^{6}$. There is no information about maximum permissible nickel concentrations in fish tissues in Turkish standards ${ }^{18}$

The minimum and maximum lead contents were $0.04 \mathrm{mg} / \mathrm{kg}$ in CAS and $1.31 \mathrm{mg} / \mathrm{kg}$ in BRT for muscles, and $0.58 \mathrm{mg} / \mathrm{kg}$ in CAS and $2.06 \mathrm{mg} / \mathrm{kg}$ in BRT for livers. Lead in the literature have been reported in the range of
$0.33-0.93 \mathrm{mg} / \mathrm{kg}$ in muscles of fish from Black and Aegean seas ${ }^{10}, 0.01-0.15$ $\mathrm{mg} / \mathrm{kg}$ in muscles of fish from Ria de Averio, Portugal ${ }^{25}, 0.40-2.44 \mathrm{mg} / \mathrm{kg}$ in muscles and 1.41-3.92 mg/kg in livers of fish from Tuzla Lagoon ${ }^{4}, 0.008-0.014$ $\mathrm{mg} / \mathrm{kg}$ in muscles and $1.35-4.39 \mathrm{mg} / \mathrm{kg}$ in livers of fish from Mediterranean sea region ${ }^{6}$. The Joint FAO/WHO Expert Committee on Food Additives established a PTWI for lead of $0.025 \mathrm{mg} / \mathrm{kg}$ body weight $/$ week $^{24}$ which was equivalent to $1.725 \mathrm{mg} /$ week for a $70 \mathrm{~kg}$ adult. By using the means of weekly fish consumption in Turkey of $140 \mathrm{~g}$ per person ${ }^{15}$ and minimum and maximum lead levels in fish, weekly intake calculated ranged from $0.006 \mathrm{mg}$ (140 g x $0.04 \mathrm{mg} / 1000 \mathrm{~g})$ to $0.183 \mathrm{mg}(140 \mathrm{~g} \mathrm{x} 1.31 \mathrm{mg} / 1000 \mathrm{~g})$ per person for lead in muscles of fish. As can be seen, the estimated PTWI of lead in this study is below the established PTWI.

The lowest and highest zinc levels in fish were found as $3.36 \mathrm{mg} / \mathrm{kg}$ in CAS and $42.6 \mathrm{mg} / \mathrm{kg}$ in SNP for muscles, and $14.1 \mathrm{mg} / \mathrm{kg}$ in CAS and $91.4 \mathrm{mg} / \mathrm{kg}$ in SNP for livers. Zinc contents in the literature have been reported in the range of $4.71-23.1 \mathrm{mg} / \mathrm{kg}$ for muscles of fish from Ria de Averio, Portugal ${ }^{25}, 10.7 \mathrm{mg} / \mathrm{kg}$ for muscles $36.4 \mathrm{mg} / \mathrm{kg}$ for livers of fish from Esmoriz-Paramos coastal lagoon, Portugal $^{22}, 4.36 \mathrm{mg} / \mathrm{kg}$ for muscles of fish from İskenderun bay, Turkey ${ }^{3}$. The Joint FAO/WHO Expert Committee on Food Additives established a PTWI for zinc of $7 \mathrm{mg} / \mathrm{kg}$ body weight/week ${ }^{24}$ which was equivalent to $490 \mathrm{mg} /$ week for a $70 \mathrm{~kg}$ adult. By using the means of weekly fish consumption in Turkey of 140 $\mathrm{g}$ per person ${ }^{15}$ and minimum and maximum zinc levels in fish, weekly intake calculated ranged from $0.47 \mathrm{mg}(140 \mathrm{~g} \mathrm{x} 3.36 \mathrm{mg} / 1000 \mathrm{~g})$ to $5.96 \mathrm{mg}(140 \mathrm{~g}$ $\mathrm{x} 42.6 \mathrm{mg} / 1000 \mathrm{~g}$ ) per person for zinc in muscles of fish. As can be seen, the estimated PTWI of zinc in this study is below the established PTWI.

One way ANOVA was performed to test the differences between stations. The differences between stations were statistically significant for cadmium, copper, manganese lead and zinc in muscles, and for copper, iron, manganese and zinc in livers $(\mathrm{p}<0.05)$

\section{CONCLUSIONS}

The results presented above clearly demonstrated that the Turkish coastal water may be faced metal pollution in particular areas for $\mathrm{Cd}, \mathrm{Cr}$ and $\mathrm{Pb}$. Because cadmium concentrations in BRT and IB, chromium in IB, and lead in BRT are higher than Turkish permissible limits. Contaminant information on broad range of metals in commercial fish is generally not available to the public. Thus, we suggest that there is a need for more information on contaminant levels in fish from Turkey or any specific regions of the world and that the public should be provided with information on exact species identification, collection location, and growth method (farmed or wild-caught). Then data on contaminant levels in fish from particular regions of the world could allow people to make informed decisions about which fish to eat to reduce their risk from the contaminants. Preventive measures should be enforced by the Turkish Coastal Guard for discharging ballast and bilge waters from ship, and industrial plants through the coastal waters should be enforced to build their water treatment plants to decrease the metal pollution in coastal waters.

\section{ACKNOWLEDGMENTS}

The authors would like to thank The Scientific \& Technological Research Council of Turkey (TÜBITAK) for their financial support (Project No: 105Y018).

\section{REFERENCES}

1. J.L. Zhou, S.M. Salvador, Y.P. Liu, M. Sequeria, Sci.Total Environ. 273, $61(2001)$

2. S. Andres, F. Ribeyre, J.N. Tourencq, A. Boudou, Sci. Total Environ. 248 , $11(2000)$.

3. A. Türkmen, M. Türkmen, Y. Tepe, İ. Akyurt, Food Chem. 91, 167 (2005).

4. M. Dural, M.Z.L. Göksu, A.A. Özak, Food Chem. 102, 415 (2007).

5. Y. Tepe, M. Türkmen, A. Türkmen, Environ. Monit. Assess. DOI 10.1007/ s 10661-007-0079-3. (2007).

6. M. Türkmen, C. Ciminli, Food Chem. 103, 670 (2007)

7. H. Hornung, G. Ramelow, Mar. Pollut. Bull. 18, 45 (1987).

8. M. Romeoa, Y. Siaub, Z. Sidoumou, M. Gnassia-Barelli, Sci. Total Environ. 232, 169 (1999).

9. M.G.M. Alam, A. Tanaka, G. Allinson, L.J.B. Laurenson, F. Stagnitti, E. Snow, Ecotox. Environ. Safe. 53, 348 (2002).

10. O.D. Uluozlu, M. Tuzen, D. Mendil, M. Soylak, Food Chem. 104, 835 (2007). 
11. Ö. Dalman, A. Demirak, A. Balc1, Food Chem. 95, 157 (2006).

12. P. Sivaperumal, T.V. Sankar, P.G.V. Nair, Food Chem. 102, 612 (2007).

13. D. Mendil, Ö.D. Uluözlü, E. Hasdemir, M. Tüzen, H. Sari, M. Suiçmez, Food Chem. 90, 175 (2005).

14. WHO. WHO Technical Report Series No. 776. Geneva (1989).

15. FAO. http://www.fao.org/es/ESS/faostat/foodsecurity/index en.htm. (2005)

16. Y. Anan, T. Kunito, S. Tanabe, I. Mitrofanov, D.G. Aubrey, Mar. Pollut. Bull. 51, 882 (2005).

17. A. Türkmen, Y. Tepe, A. Ateş, K. Gökkuş, Food Chem. 108, 800. (2008).

18. TKB. Ministry of Agriculture and Rural Affairs, Ankara, Turkey (2002).

19. A. Türkmen, M.,Türkmen, Y.,Tepe, Y. Mazlum, S. Oymael, Bull. Environ. Contam. Toxicol. 77, 186 (2006).
20. FAO Compilation of legal limits for hazardous substances in fish and fishery products, FAO Fish Circular, 764 (1983).

21. J. Tapia, E. Duran, F. Pena-Cortes, E. Hauenstein, C. Bertran, R. Schlatter, L. Vargas-Chacoff, C. Jimenez, J. Chil. Chem. Soc. 51, 901 (2006).

22. C. Fernandes, A. Fontainhas-Fernandes, F. Peixoto, M.A. Salgado, Ecotox. Environ. Safe. 66, 426 (2007).

23. S. Miniadis-Meimaroglou, C. Dimizas, L. Vassilis, A. Moukas, A. Vlachos, N. Thomaidis, V. Paraskevopoulou, M. Dasenakis, Chem. Phys. Lipids, 146, 104 (2007).

24. FAO/WHO. "Summary of Evaluations Performed by the Joint FAO/WHO Expert Committee on Food Additives (JECFA 1956-2003)", ILSI Press International Life Sciences Institute (2004).

25. B. Perez Cid, C. Boia, L. Pombo, E. Rebelo, Food Chem. 75, 93 (2001). 